\title{
Responses of microbial food web to increased allochthonous DOM in an oligotrophic subarctic lake
}

\author{
Laura Forsström ${ }^{1,3, *}$, Toni Roiha ${ }^{1,2}$, Milla Rautio ${ }^{1,2}$ \\ ${ }^{1}$ Department of Biological and Environmental Science, 40014 University of Jyväskylä, Finland \\ ${ }^{2}$ Département des sciences fondamentales and Centre for Northern Studies (CEN), Université du Québec à Chicoutimi, \\ Québec G7H 2B1, Canada \\ ${ }^{3}$ Present address: Department of Environmental Sciences, 00014 University of Helsinki, Finland
}

\begin{abstract}
Climate-induced changes in catchment area vegetation and runoff alter the quality and quantity of carbon that enters lakes, with implications for food webs in recipient water bodies. The effect of dissolved organic matter (DOM) on the ratio between heterotrophic and autotrophic biomass and productivity was studied in a subarctic, clear water lake in northern Finland. In a mesocosm experiment, natural DOM from a subarctic bog and a boreal lake was added to the lake water, doubling the initial dissolved organic carbon (DOC) concentration. Optical indices suggested that the subarctic DOM addition was more bioavailable, which was in line with the greater increase in bacterial biomass and production observed in this treatment. Both DOM additions increased the abundance of heterotrophic nanoflagellates (HNF) and decreased primary productivity. They also led to lower ratios of primary to bacterial production, autotrophic to mixotrophic algae and pigmented nanoflagellates (PNF) to HNF relative to the control samples, indicating a shift from a primary production-based food web towards one based on bacterial production. A comparable increase in DOM in the natural environment would lead to a considerable decrease in the euphotic layer and loss of areas available for primary production, resulting in a shift towards a heterotrophic production based food web.
\end{abstract}

KEY WORDS: Dissolved organic matter - Dissolved organic carbon - Subarctic $\cdot$ Microbial food web

\section{INTRODUCTION}

Permafrost thawing, soil erosion and enhanced plant growth throughout the Arctic region (ACIA 2005, Callaghan et al. 2011) all increase the transfer of organic matter from terrestrial to aquatic systems (Schuur et al. 2009). Increased availability of carbon stimulates microbial growth and respiration in lakes (Breton et al. 2009, Berggren et al. 2010a) at the expense of phytoplankton production. Transition to a net heterotrophic metabolic gas balance has been estimated to take place at dissolved organic carbon (DOC) concentrations of around $5 \mathrm{mg} \mathrm{l}^{-1}$ (Jansson et al. 2000, Prairie et al. 2002). This suggests that pelagic food webs are likely to be based on autotrophs only in very transparent, oligotrophic, low DOC lakes. Currently, high altitude and high latitude lakes which are receiving more terrestrial carbon to their waters are becoming more heterotrophic systems. Northern lakes are also becoming more DOC rich through other mechanisms, aside from climaterelated changes in the catchment. The widespread increase in the concentration of DOC in lakes across the northern hemisphere is known as brownification and has been related to changes in deposition chemistry and catchment acid-sensitivity during the process of recovery from acidification (Monteith et al. 2007). 
Although the impact of DOC on lake food webs has been extensively studied, the focus has generally been on DOC quantity, and only until recently has the effect of the quality of DOC and dissolved organic matter (DOM) on lake secondary productivity begun to receive attention (Pérez \& Sommaruga 2006, Berggren et al. 2010a, Guillemette \& del Giorgio 2011). The quality of DOM is known to be strongly related to its source (Findlay \& Sinsabaugh 2003). Autochthonous carbon (the product of in situ biological processes) is considered more labile than (terrestrially derived) allochthonous carbon (Søndergaard \& Middelboe 1995). Differences also occur among allochthonous DOM originating from different sources; forest-derived DOM tends to be more heterogeneous, containing a proportion of young, potentially bioavailable compounds, in contrast to slow degrading and more recalcitrant bog-derived DOM (Berggren et al. 2007). Labile DOM has been shown to be more important for bacterial production than refractory DOM (Moran \& Hodson 1990, Kritzberg et al. 2004). On the other hand, it seems that bacterial communities will develop according to the quality of available DOM, with some communities being more efficient in metabolizing refractory or high-molecular-weight DOM than others (Docherty et al. 2006).

The heterogeneous nature of DOM has both positive and negative effects on all trophic levels in lakes. A major negative effect of DOM is the reduction of algal growth in response to increased light attenuation (Jones 1992, Karlsson et al. 2009). Even small changes $\left(2 \mathrm{mg} \mathrm{l}^{-1}\right)$ in colored DOM (CDOM) concentration are likely to cause drastic changes in light attenuation and the spectral regime (Vincent et al. 1998), leading to a decrease in the euphotic layer. However, increased DOM levels protect organisms against the harmful effects of UV radiation (Ekelund 1993, Rautio \& Korhola 2002). In addition, DOM has been shown to change the availability of inorganic nutrients both directly and indirectly by stimulating bacterial growth (Jackson \& Hecky 1980, Stewart \& Wetzel 1980, Jones et al. 1988, Moran \& Zepp 1997, Klug 2002). Bacterial production is also coupled strongly with DOM quality (Pérez \& Sommaruga 2006, Berggren et al. 2010a). In addition to stimulating the microbial food web, DOM can also be an important nutritional source for zooplankton (Salonen \& Hammar 1986, De Lange et al. 2003).

Increased allochthonous carbon inputs are expected to have a strong impact on the competition between organisms at the base of the subarctic food web, i.e. bacterio- and phytoplankton. These microbial organisms compete for the same resources (inorganic nutri- ents) but are able to utilize different carbon sources. While phytoplankton are dependent on solar radiation as an energy source to obtain inorganic carbon, bacterioplankton have the ability to use allochthonous organic carbon sources for carbon mobilization (Moran \& Hodson 1990). In general, heterotrophic bacteria account for a higher proportion of planktonic biomass in oligotrophic lakes compared to meso- and eutrophic systems (Biddanda et al. 2001). In oligotrophic clear water lakes in particular, it is expected that increased allochthonous DOM will favor bacterioplankton and shift the ecosystem towards stronger heterotrophy (Kritzberg et al. 2004, Ask et al. 2009).

We tested these predictions experimentally by measuring the effect of adding allochthonous DOM on the biomass and productivity of heterotrophic and autotrophic organisms in an unproductive subarctic lake. As microbes respond to the quality of DOM (e.g. age, molecular structure and size) with highly variable rates and efficiency (Moran \& Hodson 1990, Ellis et al. 1999, Berggren et al. 2009), we used DOM from 2 different sources: a boreal lake and a local subarctic bog. For logistic reasons, to avoid the so-called 'bottle effect' and to imitate natural conditions (i.e. terrestrial DOM enters the lakes in pulses following the melting season and/or heavy rainfall), we focused on the short-term effects over a few days. The experiment was conducted just above the local treeline, an ecotone where lake ecosystems are expected to show strong responses to climate change (Vinebrooke \& Leavitt 2005). We also selected a lake where the initial DOC concentration was low $\left(2 \mathrm{mg} \mathrm{l}^{-1}\right)$, where minor changes in DOC levels would have a strong impact on the attenuation of light, and where doubling of DOC was expected to shift the basal pelagic production and biomass dominance from algae to bacteria. We hypothesized that an increased amount of allochthonous DOM (as an energy source and through its light-absorption characteristics) would change lake productivity by causing a shift from the dominance of autotrophic to heterotrophic organisms. We further hypothesized that the 2 DOM sources would differ in quality and would therefore lead to differences in bacterial biomass and production. Finally, drawing on the results of the enclosure experiment, we considered how a similar DOC addition would change whole-lake productivity.

\section{MATERIALS AND METHODS}

A mesocosm experiment with 9 enclosures (3 controls, $3 \times 2$ DOM additions) was conducted in August 
2008 in Lake Saanajärvi, an oligotrophic clear-water lake situated above the local treeline in northwest Finnish Lapland. The maximum depth of the lake is $24 \mathrm{~m}$, the surface area is 70 ha and the catchment area, covered by sub-alpine vegetation and bare rocky surfaces, is 460 ha. Lake Saanajärvi is a dimictic lake with a short spring overturn followed by a stratification period of circa 1.5 to $2 \mathrm{mo}$, a thermocline at around $10 \mathrm{~m}$, and an autumn overturn of $1.5 \mathrm{mo}$ (Forsström et al. 2005). Two different DOM sources were used for the experiment: (1) DOM-rich water from a bog located $100 \mathrm{~km}$ southeast of the study site $\left(68^{\circ} 29^{\prime} \mathrm{N}, 22^{\circ} 16^{\prime} \mathrm{E}\right)$, hereafter known as 'subarctic DOM' and (2) humic lake water from the small headwater Lake Mekkojärvi, located in southern Finland $\left(61^{\circ} 13^{\prime} \mathrm{N}, 2^{\circ} 08^{\prime} \mathrm{E}\right)$, hereafter known as 'boreal DOM'. The lake has a retention time of between a few and 150 d (Arvola et al. 1992) and is surrounded by a spruce Picea abies and Scots pine Pinus sylvestris forest. Bog-water was taken from the surface of a small pond within the Sphagnum bog, and water from Lake Mekkojärvi was taken with a Limnos water sampler from the lake epilimnion. The 2 sources were chosen as DOM from forests and bogs are known to differ in their bioavailability (Berggren et al. 2007). As a consequence of the presence of mycorrhizal plant roots, the DOC pool in forested soils is loaded with fresh photosynthates readily available for bacterial metabolism. In contrast, the organic carbon in bog litter is generally less bioavailable compared to forest litter because it mostly consists of of slow-degrading bryophytic material. For example, Sphagnum species, which typically dominate the vegetation, comprise recalcitrant carbon compounds.

Open-top enclosures (diameter $400 \mathrm{~mm}$, height $600 \mathrm{~mm}$ ) were made from $0.2 \mathrm{~mm}$ thick low-density polyethylene (LDPE) film with high light transparency. Enclosures were placed in Lake Saanajärvi as in Galford (2000) and filled with epilimnetic water taken from Lake Saanajärvi and filtered through a $<50 \mu \mathrm{m}$ plankton net to remove zooplankton. Water taken from the bog and from Lake Mekkojärvi was filtered through $0.2 \mu \mathrm{m}$ cellulose acetate filters to remove bacteria.
All enclosures were filled with a total volume of 421 with a target DOC concentration for the enclosures with added DOM (+DOM) of $5 \mathrm{mg} \mathrm{l}^{-1}$ (approximately 2.5 times the DOC concentration of the lake). Initial DOC concentrations of the subarctic and boreal DOM sources were 27.8 and $20 \mathrm{mg} \mathrm{l}^{-1}$, respectively (Table 1), so to achieve this target the added volumes were 4.7 and 6.51 , respectively. This diluted the lake water in the +DOM treatments by $10 \%$ (subarctic enclosures) and 13\% (boreal enclosures) in comparison to the control enclosures. The nutrient concentrations in the added DOM were too small, when diluted with the lake water, to have an influence on biological productivity (subarctic DOM: $\mathrm{NO}_{3}<2, \mathrm{NO}_{2}=7$, $\mathrm{NH}_{4}=7, \mathrm{PO}_{4}=7 \mu \mathrm{g} \mathrm{l}^{-1}$; boreal DOM: $\mathrm{NO}_{3}<2, \mathrm{NO}_{2}=$ 13, $\mathrm{NH}_{4}=4, \mathrm{PO}_{4}=11 \mu \mathrm{g} \mathrm{l}^{-1}$ ).

Table 1. Environmental parameters of mesocosms (enclosures) in a subarctic Finnish lake (above) and parameters related to dissolved organic matter (DOM) spectroscopy (below), for control enclosures/open water and for the DOM sources. Values for the enclosures are averages \pm SD. Nutrients were analyzed only at the end of the experiment, other parameters were analyzed during every sampling. P-tot: total phosphorus; N-tot: total nitrogen; DOC: dissolved organic carbon; $P_{\text {max }}^{*}$ : maximum chl a normalized photosynthetic capacity; $E_{\mathrm{k}}$ : light adaptation parameter, i.e. light intensity at the onset of saturation; $\alpha^{*}$ : initial slope of the $P-E$ curve normalized to chl $a_{i} a_{\mathrm{CDOM}}$ : absorption coefficient of colored DOM; $a_{254}: a_{365}$ : absorbance ratio between 254 and $365 \mathrm{~nm} ; S$ : spectral slope (of wavelength range shown); $S_{\mathrm{R}}$ : slope ratio, i.e. the ratio of $S_{275-295}$ to $S_{350-400 ;}$ SUVA $_{254}$ : specific UV absorbance at $254 \mathrm{~nm}$

\begin{tabular}{|c|c|c|c|}
\hline & Control & $\begin{array}{l}\text { Enclosures - } \\
+ \text { DOM subarctic }\end{array}$ & +DOM boreal \\
\hline \multicolumn{4}{|l|}{ Environmental parameters } \\
\hline Temperature & $10.5 \pm 0.07$ & $10.5 \pm 0.06$ & $10.6 \pm 0.06$ \\
\hline $\mathrm{pH}$ & $7.5 \pm 0.02$ & $7.4 \pm 0.01$ & $7.3 \pm 0.01$ \\
\hline Conductivity $\left(\mu \mathrm{cm}^{-1}\right)$ & $22.2 \pm 0.09$ & $21.7 \pm 0.18$ & $21.8 \pm 0.06$ \\
\hline P-tot $\left(\mu g \mathrm{l}^{-1}\right)$ & $7.3 \pm 3.3$ & $9.1 \pm 2.9$ & $7.1 \pm 1.3$ \\
\hline $\mathrm{NO}_{3}-\mathrm{N}\left(\mu \mathrm{g} \mathrm{l}{ }^{-1}\right)$ & $2.0 \pm 0.00$ & $<2$ & $<2$ \\
\hline N-tot $\left(\mu \mathrm{g} \mathrm{l}^{-1}\right)$ & $153.3 \pm 8.8$ & $250.0 \pm 40.0$ & $246.7 \pm 21.9$ \\
\hline $\mathrm{DOC}\left(\mathrm{mg} \mathrm{l}^{-1}\right)$ & $2.08 \pm 0.08$ & $4.75 \pm 0.17$ & $5.56 \pm 0.11$ \\
\hline$P_{\max }^{*}\left(\mathrm{mg} \mathrm{C} \mathrm{mg}^{-1} \mathrm{chl} \mathrm{a}^{-1}\right)$ & $1.14 \pm 0.46$ & $0.51 \pm 0.19$ & $0.47 \pm 0.18$ \\
\hline$E_{\mathrm{k}} \mu \mathrm{mol}$ photons $\left(\mathrm{m}^{-2} \mathrm{~s}^{-1}\right)$ & $49.9 \pm 20.7$ & $46.3 \pm 18.1$ & $50.5 \pm 15.6$ \\
\hline \multirow[t]{2}{*}{$\alpha^{*}$} & $0.034 \pm 0.01$ & $0.011 \pm 0.00$ & $0.009 \pm 0.00$ \\
\hline & Open water & $\begin{array}{l}\text { - DOC sources } \\
+ \text { DOM subarctic }\end{array}$ & +DOM boreal \\
\hline \multicolumn{4}{|l|}{ Spectroscopy parameters } \\
\hline $\mathrm{DOC}\left(\mathrm{mg} \mathrm{l}^{-1}\right)$ & 1.9 & 27.8 & 20.0 \\
\hline$a_{\mathrm{CDOM}}$ at $320 \mathrm{~nm} \mathrm{~m}^{-1}$ & 4.5 & 138.2 & 140.5 \\
\hline$a_{\mathrm{CDOM}}$ at $440 \mathrm{~nm} \mathrm{~m}^{-1}$ & 1.0 & 20.9 & 23.2 \\
\hline$a_{254}: a_{365}$ & 5.1 & 4.1 & 4.0 \\
\hline$a^{*}{ }_{\mathrm{CDOM}}$ at $320 \mathrm{~nm} \mathrm{~m}^{-1}$ & 2.4 & 5.0 & 7.0 \\
\hline$S_{300-650 \mathrm{~nm}}$ & 0.0127 & 0.0151 & 0.0142 \\
\hline$S_{275-295 \mathrm{~nm}}$ & 0.0174 & 0.0117 & 0.0124 \\
\hline$S_{350-400 \mathrm{~nm}}$ & 0.0130 & 0.0171 & 0.0158 \\
\hline$S_{\mathrm{R}}$ & 1.34 & 0.68 & 0.78 \\
\hline SUVA $_{254}$ & 2.9 & 4.5 & 6.4 \\
\hline
\end{tabular}


Enclosures were sampled on Days 1 (24 h after DOM addition), 3 and 5 after the initiation of the experiment. Water temperature, $\mathrm{pH}$ and conductivity were all measured in situ using a YSI 63 handheld $\mathrm{pH}$ and conductivity meter. Samples for nutrients were only collected at the end of the experiment, and the analyses were carried out by the Lapland Regional Environmental Centre using the standard methods of the National Board of Waters in Finland (SFS 1990, $2004 a, b)$. The concentration of DOC was analyzed as non-purgeable organic carbon at the Lammi Biological Station with a Shimadzu TOC-VCPH Analyzer. Measured indices of heterotrophic biomass and productivity included bacterial biomass and production, and the abundance of heterotrophic nanoflagellates (HNF). Autotrophic measures included chlorophyll a (chl a), abundance of picoautotrophs and pigmented nanoflagellates (PNF), and abundance, biomass and production of phytoplankton.

DOM absorbance was analyzed from the lake water and from both DOM sources using a Cary 300 UV-Vis spectrophotometer (Varian). For the analysis, $50 \mathrm{ml}$ of sample water was filtered through prerinsed $0.2 \mu \mathrm{m}$ cellulose acetate filters and stored at $4^{\circ} \mathrm{C}$ in the dark in acid-cleaned and pre-combusted amber glass bottles. DOM absorption was measured in dual-beam mode every $1 \mathrm{~nm}$ over the wavelengths 250 to $850 \mathrm{~nm}$ and corrected against Milli-Q water and for the absorption offset. The absorption coefficient at $320 \mathrm{~nm}\left(a_{\mathrm{CDOM}} 320\right)$ was used to quantify CDOM, the absorption coefficient at $440 \mathrm{~nm}$ as a measure of CDOM color, and DOC-specific $a_{\mathrm{CDOM}}$ $320\left(a^{*}{ }_{\text {CDOM }} 320\right)$ as a proxy of the degree of DOM color. Spectral slopes $(S)$ of different wavelength ranges (275 to 295,350 to 400 and 300 to $650 \mathrm{~nm}$ ), as well as the slope ratio $\left(S_{\mathrm{R}}\right)$, i.e. the ratio of $S_{275-295}$ to $S_{350-400}$, were calculated to obtain information on DOM quality (Helms et al. 2008). Specific UV absorbance (SUVA) at $254 \mathrm{~nm}$, defined as the absorbance at $254 \mathrm{~nm}$ measured in inverse meters $\left(\mathrm{m}^{-1}\right)$ divided by the DOC concentration ( $\mathrm{mg} \mathrm{l}^{-1}$ ) was used to quantify the variation in the source of carbon (Weishaar et al. 2003). We also calculated the absorbance ratio between 254 and $365 \mathrm{~nm}\left(a_{254}: a_{365}\right)$, which can be used as an additional index of DOM character (Ågren et al. 2008) and has been previously found to correlate with bacterial growth efficiency (BGE) (Berggren et al. 2007, 2009).

Bacterial biomass was calculated as a function of bacterial abundance and biovolume. The abundance was determined from black polycarbonate filters (pore size $0.2 \mu \mathrm{m}$, diameter $25 \mathrm{~mm}$ ) stained with 4', 6diamidino-2-phenylindole (DAPI) (Porter \& Feig
1980). Samples were counted under UV excitation with an epifluorescence microscope at 1000× magnification and a minimum of 400 cells were counted from each replicate. Bacterial biovolume estimations were carried out from digital images using the Cell C program (Selinummi et al. 2005) and biovolumes were converted to biomasses using the coefficient $308 \mathrm{fg} \mathrm{C} \mathrm{mm}^{-3}$ (Fry 1988). Bacterial production was estimated using ${ }^{3} \mathrm{H}$-leucine (specific activity: $73 \mathrm{Ci}$ $\mathrm{mmol}^{-1}$ ) incorporation (Kirchman et al. 1985). Productivity measurements started 2 to $6 \mathrm{~h}$ after the sampling with triplicate samples and duplicate controls. Leucine concentration (30 nM) and incubation time were estimated from Lake Saanajärvi specific saturation and incubation time curves. Samples were incubated under dark and cold $\left(6.4^{\circ} \mathrm{C}\right)$ conditions for $3 \mathrm{~h}$. The incubation temperature was approximately $4{ }^{\circ} \mathrm{C}$ lower than the temperature in the enclosures and likely resulted in a slight but equal underestimation of the bacterial productivity (Adams et al. 2010) in all enclosures. After termination with trichloroacetic acid (TCA: 5\% final concentration), the samples were frozen $\left(-20^{\circ} \mathrm{C}\right)$ and stored in the dark until centrifuging and radioassaying with a RackBeta scintillation counter as in Smith \& Azam (1992).

HNF and PNF were prepared for microscopy by filtering 20 to $50 \mathrm{ml}$ DAPI-stained water through a $0.6 \mu \mathrm{m} 25 \mathrm{~mm}$ black polycarbonate membrane as in Safi \& Hall (1997). Slides were frozen until examination under UV excitation at $1000 \times$ magnification using a Leica Leitz DMRB epifluorescence microscope. Green excitation was used to discriminate between colorless HNF, and PNF with chloroplasts and pigments.

For chl a quantification, $500 \mathrm{ml}$ of water from each enclosure was filtered through Whatman GF/F filters and frozen. Filters were later extracted overnight in $10 \mathrm{ml}$ ethanol (90\% v/v) and analyzed with a Hitachi F-4000 fluorescence spectrophotometer as in Jefferey \& Humphrey (1975).

Abundances of the autotrophic community groups were assessed using 3 different sampling methods; samples were collected separately for picoautotrophs, PNF and phytoplankton abundance. There is a slight overlap in the obtained results as, for example, some autotrophs are included in both PNF and phytoplankton samples. However, there are important functional differences among the 3 categories used and we therefore present the results according to these groupings. Furthermore, as the epifluorescence technique cannot distinguish between cells that were dead at the time of sampling from those that were alive, both Utermöhl counts (Utermöhl 
1958) and the epifluorescence technique are required to estimate abundance.

Water samples $(50 \mathrm{ml})$ for the analysis of picoautotrophs were first pre-filtered through $3 \mu \mathrm{m}$ porosity membranes and then under low pressure onto $0.2 \mu \mathrm{m}$ Anodiscs, mounted on microscope slides with immersion oil and stored at $-20^{\circ} \mathrm{C}$. The number of cells (minimum of 400 cells on each slide) was counted with a fluorescence microscope at 1000x magnification using a green excitation filter set to detect chlorophyll autofluorescence.

Phytoplankton abundance, biovolume and species composition were analyzed from Lugol-preserved samples using the Utermöhl technique (Utermöhl 1958). In addition to sampling the enclosures, phytoplankton was analyzed from the open water adjacent to the enclosures to assess the effect of the experimental design. The phytoplankton growth rate, $r$, for the most dominant species in terms of biovolume was calculated using:

$$
r=\ln \left(N_{t} / N_{0}\right) / t
$$

where $N_{t}$ and $N_{0}$ are the biovolumes at the end and at the beginning of the experiment, respectively (Reynolds 2006).

Photosynthesis was analyzed in situ with the ${ }^{14} \mathrm{C}$ method modified from Rae \& Vincent (1998) using a set of polyethylene bags (Whirlpak) with various screens to give a light transmission series of $0,6,25$, 60 and $100 \%$ of ambient irradiance. Three replicates of $20 \mathrm{ml}$ sample water spiked with ${ }^{14} \mathrm{C}$-bicarbonate (final concentration $0.2 \mu \mathrm{Ci} \mathrm{ml}{ }^{-1}$ ) were incubated in each bag for $2 \mathrm{~h}$. After incubation, samples were filtered on GF/F filters and stored frozen. Before the laboratory analysis, $0.25 \mathrm{ml} 0.5 \mathrm{~N} \mathrm{HCl}$ was added to each filter in order to remove unbound ${ }^{14} \mathrm{C}$. For radioactivity counting, $5 \mathrm{ml}$ of a scintillation cocktail was added to each sample, and radioactivity was counted after a $24 \mathrm{~h}$ dark incubation with a RackBeta counter.

Photosynthetic rate to irradiance $(P-E)$ was calculated based on a $P$ versus $E$ model described by Platt et al. (1980). Primary productivity (PP) values (average and standard error of 3 replicate incubations) were plotted and fitted with the following regression:

$$
P=p\left(1-\mathrm{e}^{-\alpha I / p}\right) \mathrm{e}^{-\beta I / p}
$$

where $P\left(\mathrm{mg} \mathrm{C} \mathrm{m}^{-2} \mathrm{~h}^{-1}\right)$ (the dependent variable, on the $y$-axis) is the photosynthesis rate at a given photosynthetically active radiation (PAR) intensity $I\left(\mathrm{~W} \mathrm{~m}^{-2}\right)$ (independent variable, on the $x$-axis); $p$ stands for the theoretical maximum photosynthesis rate if there were no photoinhibition, $\alpha$ describes the initial slope or increase of photosynthesis at low light intensities, and $\beta$ attributes for the photoinhibition effect (Platt et al. 1980). $E_{\mathrm{k}}$, the light adaptation parameter, i.e. light intensity at the onset of saturation (Talling 1957), was obtained from $p$ and $\alpha$ as $E_{\mathrm{k}}=p / \alpha$. Daily productivity (mg C mg ${ }^{-1}$ chl $a \mathrm{~m}^{-2} \mathrm{~d}^{-1}$ ) for the epilimnion of Lake Saanajärvi was integrated from the $P$ - $E$ curve based on the correlation between DOC and light attenuation, measured as diffuse attenuation coefficient $\left(K_{\mathrm{d}}\right)$ for PAR $\left(\mathrm{r}^{2}=0.93\right.$, calculated for a set of 18 lakes in NW Finnish Lapland) (L. Forsström unpubl. data). The DOC-correlated $K_{\mathrm{d}}$ PAR values for the control, subarctic and boreal treatments were 0.22, 0.8 and $0.7 \mathrm{~m}^{-1}$, respectively. Earlier studies also showed that $>85 \%$ of the between-lake variation in $K_{\mathrm{d}}$ is explained by differences in DOC concentration (Morris et al. 1995), which suggests that our light attenuation coefficients and hence water column integrated primary production values were close to true values.

Two-way ANOVA was used to test the effects of the DOC source (subarctic, boreal, control) and time (1, 3 and $5 \mathrm{~d}$ after the start of the experiment) on response variables that included heterotrophic and autotrophic biomass and productivity. DOC source and time were considered as fixed factors in the analysis. Normality and homogeneity of variance were checked with visual examination of residuals (Montgomery 1991). Logarithmic (base 10) transformations were applied to $\mathrm{PP}$ and the ratio of PP to bacterial production (BP) to achieve the ANOVA assumptions. When a factor was significant, an a posteriori multiple comparison test (Tukey-Kramer) was carried out to identify differences. The software JMP (SAS Institute) was used for all tests. A threshold of significance of 0.05 was adopted for all statistical tests.

\section{RESULTS}

\section{Water chemistry and DOM quality}

There were no significant differences in the measured water chemistry between the controls and treatments, with the exception of an increase in total nitrogen with both DOM additions and a slight increase in total phosphorus in the subarctic DOM enclosure (Table 1). DOC concentrations were approximately twice as high in the +DOM enclosures compared to the control enclosures.

Both DOM sources showed a high absorption of $\mathrm{CDOM}$ at wavelengths 320 and $440 \mathrm{~nm}$, indicating high CDOM concentration and color, respectively. 
They also showed signs of terrestrial dominance (high $a^{*}{ }_{\text {CDOM, }}$ high SUVA), boreal DOM more so than subarctic (Table 1). The lower $S_{\mathrm{R}}$ of subarctic DOM might indicate higher levels of degradation compared to boreal DOM. The ratio of $a_{254}: a_{365}$, a proxy for allochthonous organic carbon contents of low molecular weight compounds, was smaller for +DOM sources (subarctic DOM: 4.1; boreal DOM: 4.0) compared to the control (5.1).

\section{Heterotrophic micro-organisms}

Bacterial biomass varied between 11.1 and $29.1 \mu \mathrm{g}$ $\mathrm{ml}^{-1}$ during the experiment and was highest and statistically different from the control in the +DOM subarctic treatment (Fig. $1 \mathrm{~A}_{;} F_{2.16}=6.80, \mathrm{p}=0.0073$ ). Biomass also increased in the +DOM boreal treatment but the increase was not statistically significant compared to the control.
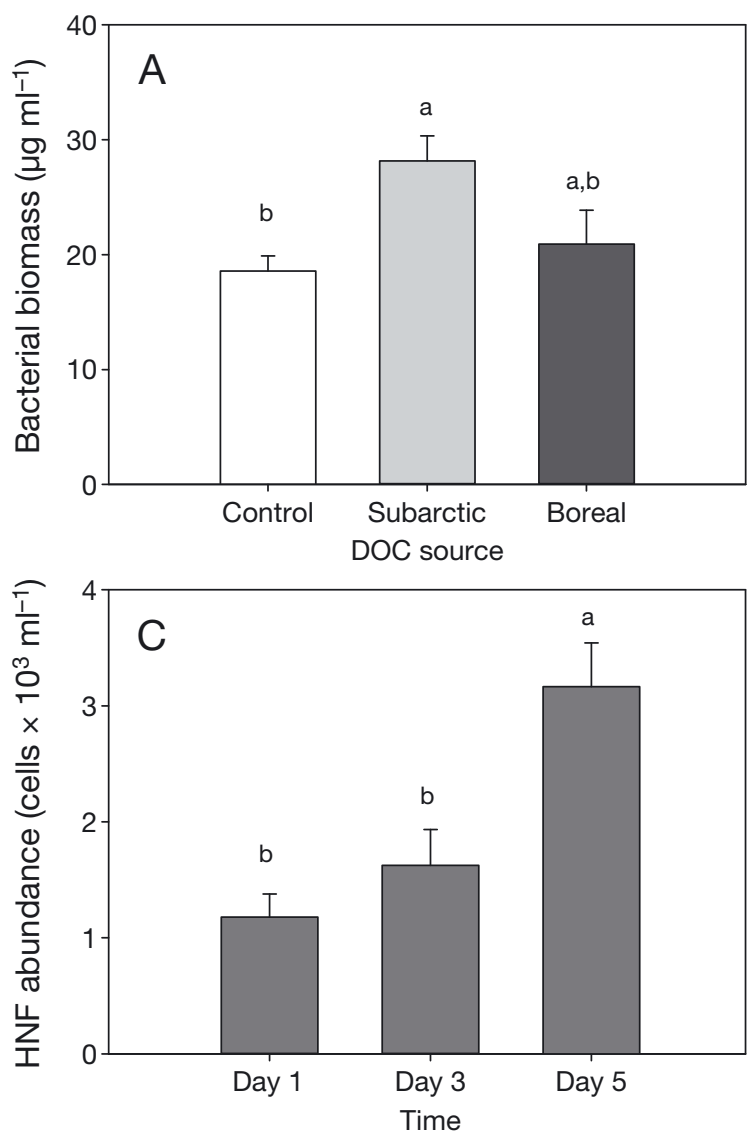

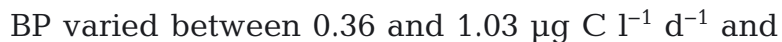
was controlled by both the DOM additions and the time of the experiment (Fig. $1 B_{;} F_{4.17}=11.01, p<$ 0.0001). BP was strongly stimulated by the + DOM subarctic treatment, as evidenced by $40 \%$ higher production in comparison to the control and +DOM boreal enclosures at the beginning of the experiment (Fig 1B). However, the differences levelled off afterwards and there were no differences between the treatments towards the end of the experiment. In both DOM treatments, BP was statistically lower at the end of the experiment compared to the beginning of the experiment (Fig. 1B).

The abundance of HNF varied between 0.4 and $3.9 \times 10^{3}$ cells $\mathrm{ml}^{-1}$. The abundance increased significantly in all treatments during the experiment (Fig. $1 C_{;} F_{2.17}=53.80, p<0.0001$ ) and was significantly higher in both +DOM treatments compared to the control (Fig. 1D; $F_{2.17}=36.97$, p < 0.0001).
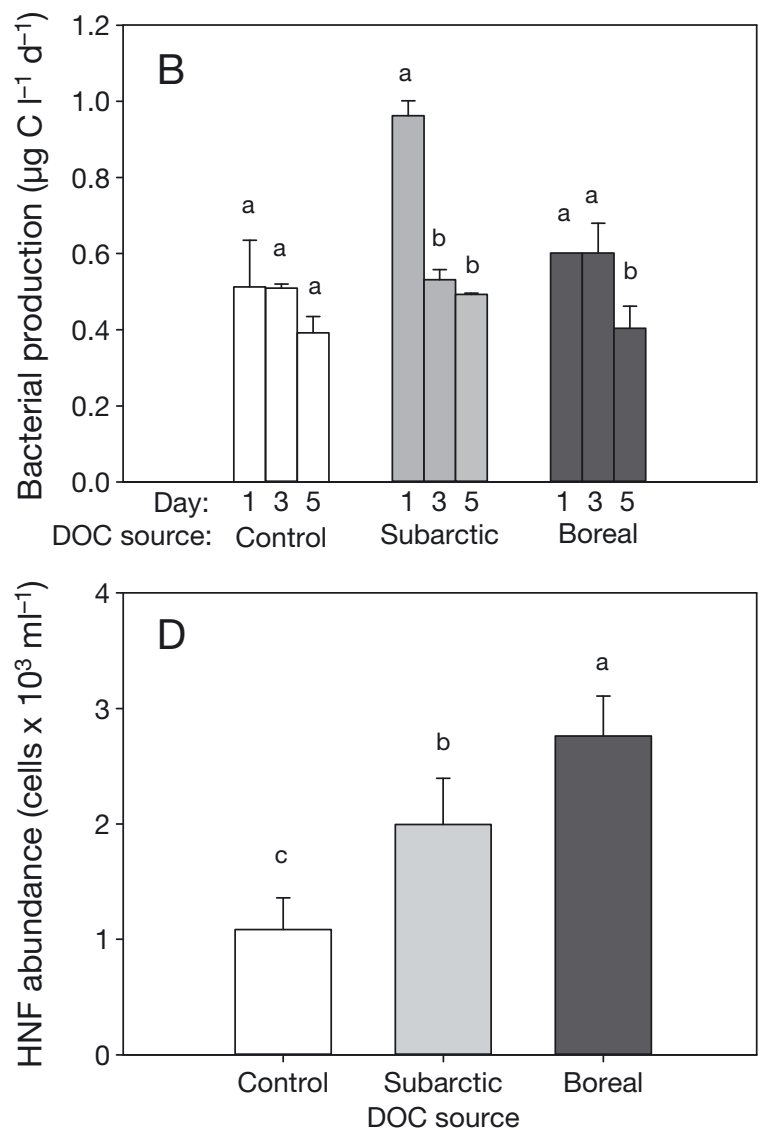

Fig. 1. Response of heterotrophic organisms over $5 \mathrm{~d}$ following the addition of dissolved organic matter (DOM) from a subarctic bog (Subarctic) and a boreal lake (Boreal) to enclosures in a subarctic Finnish lake. (A) Bacterial biomass; (B) bacterial productivity; $(C, D)$ heterotrophic nanoflagellate (HNF) abundance. For each variable, only the statistically significant factors are shown (DOC source, time, or the interaction DOC source $\times$ time). Different letters above bars indicate statistically different values. In (B) the multiple comparison letters are shown within DOC source only. Error bars are SE 


\section{Autotrophic food web}

Chl a concentration varied between 0.3 and $2.2 \mu \mathrm{g}$ $\mathrm{l}^{-1}$ and increased significantly during the experiment in all enclosures (Fig. $2 \mathrm{~A}_{i} F_{2.17}=4.58, \mathrm{p}=0.026$ ), but no difference between the treatments was found.

The abundance of PNF varied between 1.0 and 6.4 $\times 10^{3}$ cells ml $^{-1}$. Similarly to chl a concentration, the abundance increased significantly during the exper- iment in all enclosures (Fig. 2B; $F_{2.17}=31.31, \mathrm{p}<$ 0.0001), but there was no difference between the treatments.

Picoautotroph abundance varied between 0.8 and $2.7 \times 10^{4} \mathrm{cells} \mathrm{ml}^{-1}$. The abundance increased during the experiment in all treatments (Fig. 2C; $F_{2.17}=$ $10.01, \mathrm{p}=0.0013$ ) and was significantly higher in the + DOM boreal treatment compared to the control (Fig. $2 \mathrm{D} ; F_{2.17}=6.29, \mathrm{p}=0.0090$ ).
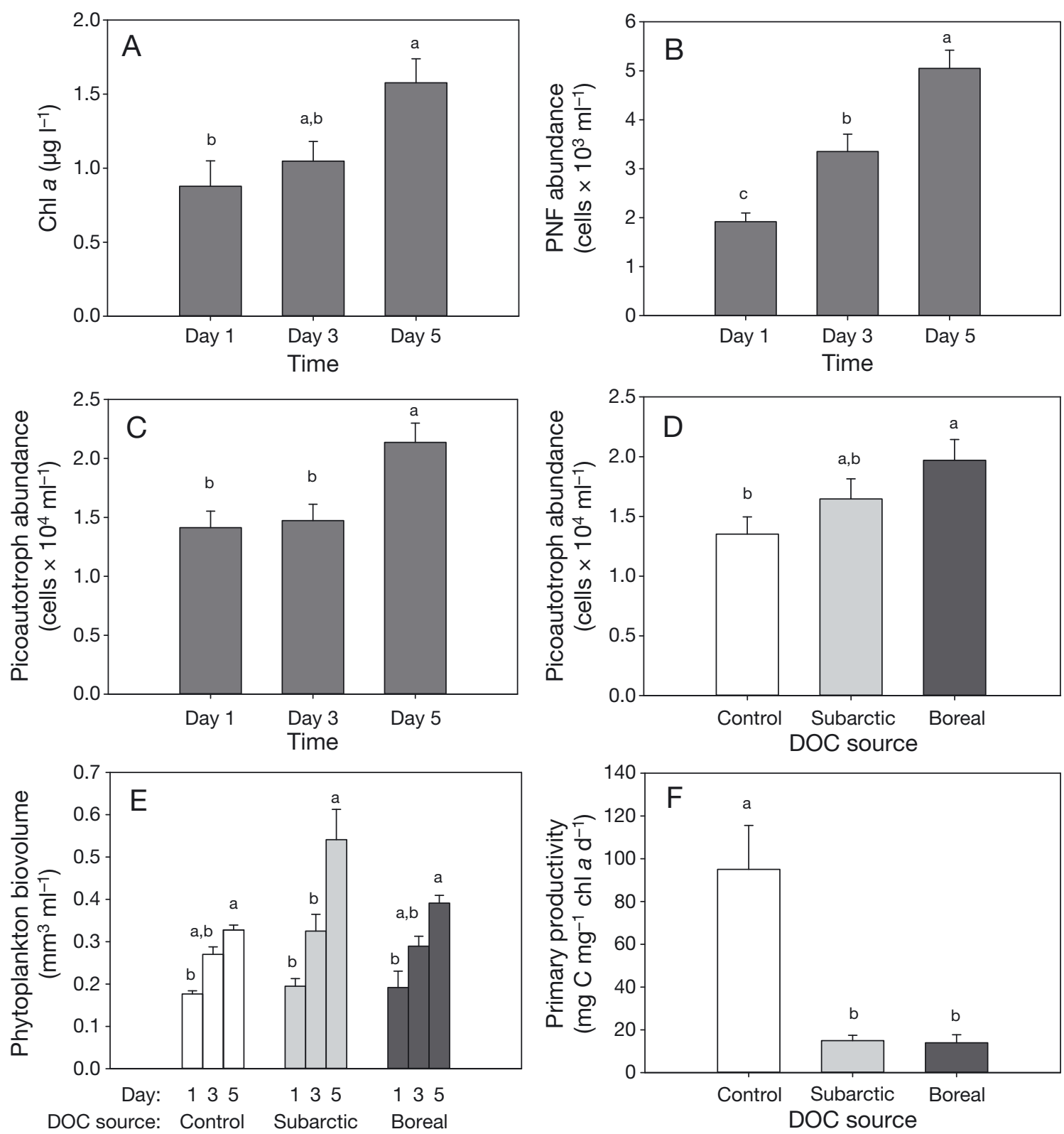

Fig. 2. Response of autotrophic organisms over $5 \mathrm{~d}$ following the addition of DOM to enclosures in a subarctic Finnish lake. (A) $\mathrm{Chl} a_{i}(\mathrm{~B})$ pigmented nanoflagellate (PNF) abundance, $(\mathrm{C}, \mathrm{D})$ picoautotroph abundance; (E) phytoplankton biovolume; (F) primary productivity. For each variable only the statistically significant factors are shown (DOC source, time, or the interaction DOC source $\times$ time). Different letters above bars indicate statistically different values. In (E) the multiple comparison letters are shown within DOC source only. Error bars are SE 
Table 2. Exponential growth rate $(r)$ (mean \pm SE) of the most dominant phytoplankton species in a subarctic Finnish lake, and in control enclosures, and enclosures following the addition of dissolved organic matter (DOM) from a subarctic bog (+DOM subarctic) and a boreal lake (+DOM boreal)

\begin{tabular}{|lrrrr|}
\hline Enclosures & Open water & Control & +DOC subarctic & +DOC boreal \\
\hline Cyclotella sp. & -0.08 & $0.02 \pm 0.00$ & $0.03 \pm 0.02$ & $0.08 \pm 0.04$ \\
Dinobryon crenulatum & 0.11 & $0.30 \pm 0.02$ & $0.29 \pm 0.05$ & $0.33 \pm 0.04$ \\
Uroglena sp. & 0.08 & $0.05 \pm 0.01$ & $0.49 \pm 0.09$ & $0.26 \pm 0.16$ \\
Pseudopedinella sp. & 0.20 & $0.36 \pm 0.08$ & $0.41 \pm 0.15$ & $0.43 \pm 0.06$ \\
Plagioselmis sp. & -0.47 & $-0.04 \pm 0.09$ & $0.11 \pm 0.05$ & $0.12 \pm 0.10$ \\
\hline
\end{tabular}

Phytoplankton biovolume varied between 0.2 and $0.6 \mathrm{~mm}^{3} \mathrm{l}^{-1}$ and increased during the experiment in all treatments and more so in the +DOM treatments (Fig. $2 \mathrm{E}_{;} F_{4.17}=3.19, \mathrm{p}=0.0398$ ). At the end of the experiment the biovolume was significantly higher in the +DOM subarctic treatment $\left(0.5 \mathrm{~mm}^{3} \mathrm{l}^{-1}\right)$ in comparison to the control $\left(0.3 \mathrm{~mm}^{3} \mathrm{l}^{-1}\right)$. Higher biovolume in the +DOM subarctic treatment was mainly caused by an increase in mixotrophic chrysophyte species, especially Uroglena sp. and to some extent a small cryptophyte belonging to the genus Plagioselmis (Table 2). The growth rates of other dominant species, such as the strictly autotrophic small centric diatom, Cyclotella sp. and 2 small chrysophytes, Dinobryon crenulatum and Pseudopedinella sp., did not show any substantial difference between treatments (Table 2). Most species had lower growth rates in the open water compared to control enclosures, with the exception of the large colonial Uroglena sp.

The ratio of algal biovolume to chl a varied from 172 (control, Day 1) to 446 (+DOM subarctic, Day 5). It was always highest in +DOM subarctic and, with the exception of Day 3, it was lowest in control enclosures, but the differences were not statistically significant.

The DOM additions also had an impact on the light milieu in the enclosures and associated photosynthetic parameters (Table 1). $E_{\mathrm{k}}$, the index of light saturation, varied from 16 to $88 \mu \mathrm{mol}$ photons $\mathrm{m}^{-2} \mathrm{~s}^{-1}$ in the control enclosures, from 12 to $52 \mu \mathrm{mol}$ photons $\mathrm{m}^{-2} \mathrm{~s}^{-1}$ in +DOM subarctic, and from 22 to $74 \mu \mathrm{mol}$ photons $\mathrm{m}^{-2} \mathrm{~s}^{-1}$ in +DOM boreal. Maximum chl a normalized photosynthetic capacity $\left(P_{\max }^{*}\right)$ was on average 2-fold higher in the control than in the +DOM enclosures. The initial slope of the $P$-E curve normalized to $\mathrm{chl} a, \alpha^{*}$, which describes the initial increase of photosynthesis at low light intensities, was also highest in the control enclosures (Table 1). PP integrated to the water column respective to the epilimnion (0 to $10 \mathrm{~m}$ ) of the lake $\left(\mathrm{mg} \mathrm{C} \mathrm{mg}^{-1} \mathrm{chl} a\right.$ $\mathrm{m}^{-2} \mathrm{~d}^{-1}$ ) was significantly suppressed by the +DOM treatments (Fig. 2F; $F_{2.23}=16.40, \mathrm{p} \leq$ 0.0001).

Based on previously calculated correlations between DOC and $K_{\mathrm{d}}$ PAR $\left(\mathrm{r}^{2}=0.93\right)$ and between DOC and $K_{\mathrm{d}}$ $320 \mathrm{~nm}\left(\mathrm{r}^{2}=0.90\right)$ for the lakes in the study region (L. Forsström unpubl.), we estimated that increases in DOC comparable to this experiment would lead to a reduction in the penetration depth of $1 \%$ PAR from 21 to $6.5 \mathrm{~m}$ (+DOM subarctic) and $5.7 \mathrm{~m} \mathrm{(+DOM}$ boreal), and a reduction in penetration of $1 \% 320 \mathrm{~nm}$ from 2 to $0.4 \mathrm{~m}$ (+DOM subarctic) and $0.3 \mathrm{~m} \mathrm{(+DOM}$ boreal). Inside the enclosures, $88 \%$ of PAR penetrated to the bottom of the control enclosures and $<60 \%$ to the bottom of the +DOM enclosures. For UV radiation, the difference was larger: while $26 \%$ of UV reached the bottom of the control enclosures, $<0.1 \%$ of UV penetrated to the bottom of +DOM enclosures. In Lake Saanajärvi, the area where the euphotic layer reaches the lake bottom would decrease from 58 ha $(83 \%$ of the total lake area) to approximately 24 ha $(34 \%$ of the total lake area) with a DOC increase comparable to this experiment (Fig. 3).

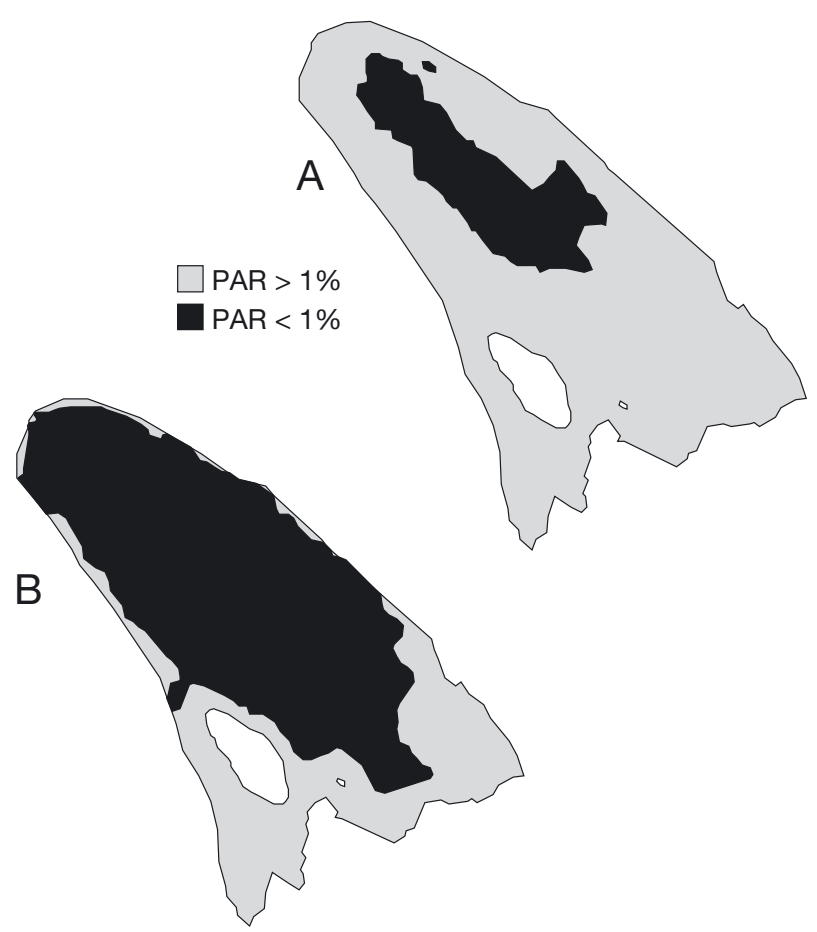

Fig. 3. Whole-lake effects of increased allochthonous DOM. Estimated euphotic area of the lake bottom with (A) current DOC concentration and (B) a DOC increase comparable to DOC additions used in the experiment. PAR: photosynthetically active radiation 

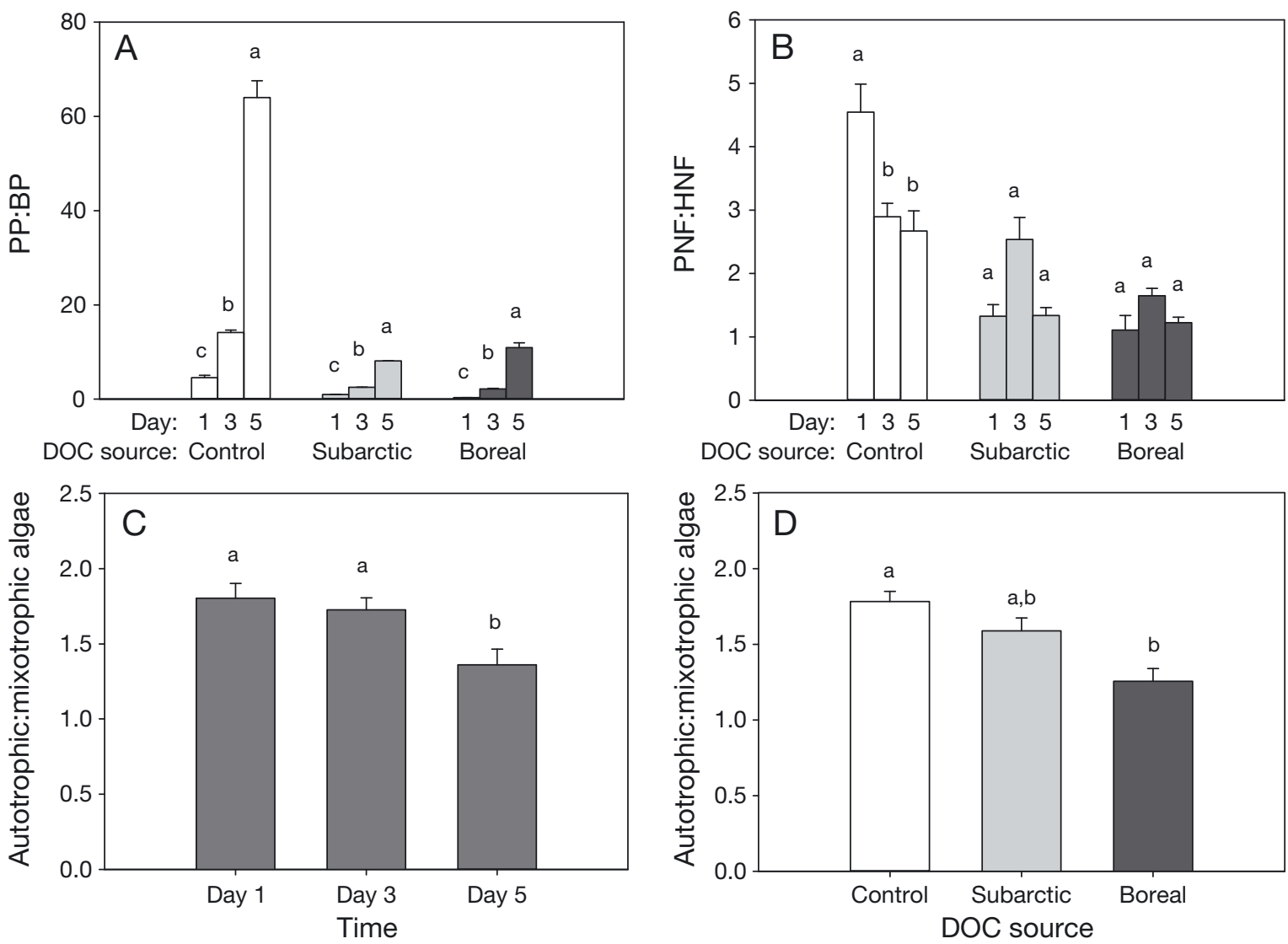

Fig. 4. Shifts in autotrophic versus heterotrophic processes over $5 \mathrm{~d}$ following the addition of DOM to enclosures in a subarctic Finnish lake. (A) Epilimnetic primary production:bacterial production (PP:BP); (B) pigmented nanoflagellates:heterotrophic nanoflagellates (PNF:HNF); and (C,D) autotrophic algae:mixotrophic algae. For each variable only the statistically significant factors are shown (DOC source, time, or the interaction DOC source $\times$ time). Different letters above bars indicate statistically different values. In (A) and (B) the multiple comparison letters are shown within DOC source only. Error bars are SE

\section{Shifts between autotrophic and heterotrophic processes}

The epilimnetic ratio of $\mathrm{PP}$ to $\mathrm{BP}$, calculated based on $P$-E curves and the correlation of DOC and $K_{\mathrm{d}}$ $\mathrm{PAR}$, increased significantly in all treatments during the experiment (Fig. $4 \mathrm{~A}_{;} F_{4.17}=35.23, \mathrm{p} \leq 0.0001$ ). It was always highest in the control enclosures, while the $2+$ DOM treatments did not differ statistically from each other.

The ratio of PNF to HNF decreased in all treatments throughout the experiment, although the decrease was statistically significant only in the control (Fig. 4B; $F_{4.17}=9.30, \mathrm{p}=0.0004$ ). The control also had statistically highest PNF:HNF ratio throughout the experiment in comparison to the +DOM treatments.

The ratio of autotrophic to mixotrophic algae significantly decreased in all treatments towards the end of the experiment (Fig. $4 C_{i} F_{2.17}=11.45, p=$
0.0007). Both +DOM treatments had a smaller autotrophic to mixotrophic algae ratio, although only the + DOM boreal treatment differed significantly from the control (Fig. $4 \mathrm{D}_{;} F_{2.17}=6.67 ; \mathrm{p}=0.0073$ ).

\section{DISCUSSION}

As expected, the DOM additions doubled the DOC concentration in the treatment enclosures and reached the level that is estimated to shift an aquatic ecosystem from an autotrophic to a heterotrophic based food web (Jansson et al. 2000, Prairie et al. 2002). The added DOM was poor in nutrients and did not increase the inorganic nutrient pool in the treatments in comparison to the control. Other physical and chemical parameters between the control and treatments were also similar, which allowed us to estimate the unique effect of DOM quantity and quality on the microbial food web. 
The characteristics of the subarctic (bog) and boreal (lake) DOM, measured as DOM spectroscopy, differed markedly from the control DOM but less from each other. Results from DOM spectroscopy indicated the bog DOM to be more bioavailable with a higher ratio between absorbance at 254 and $365 \mathrm{~nm}$ - indicative of low molecular weight compounds (Berggren et al. 2010b) - and a lower SUVA $_{254}$, which however is somewhat in contrast to what is generally reported for the quality of CDOM in organic matter exported from coniferous forest and bogs (Ågren et al. 2008, Berggren et al. 2010a). Our sampling took place in the beginning of July after a relatively dry period, which could explain the 'lack of quality' in the boreal DOM, because DOM is primarily exported to aquatic systems during episodes when discharge is high and previously unsaturated soil horizons become activated. A bioassay experiment conducted in Lake Mekkojärvi estimated that $95 \%$ of the allochthonous DOM of the lake is refractory to immediate bacterial utilization (Tulonen 2004) and the annual primary production of the lake is very low, i.e. $<10 \mathrm{~g} \mathrm{C} \mathrm{m}^{-2}$ (Salonen et al. 2005). This suggests that Lake Mekkojärvi contains DOM that is less bioavailable than DOM in many other boreal forest lakes. The difference in the degree of pigmentation per unit carbon between the 2 DOM sources could be due to differences in the degree of photodegradation or allochthony, but it could also indicate differences in iron concentration or the amount of non-humic allochthonous fractions, unfortunately not analyzed within this study.

Despite the apparent similarities in DOM optical variables, the heterotrophic community reacted differently to the 2 DOM additions. Subarctic DOM additions had a positive effect on bacterial biomass and productivity, while these variables in the +DOM boreal enclosures remained at the same level as in the control enclosures. HNF abundance reacted positively to both DOM additions and more so to the boreal DOM; this may partly explain the smaller bacterial biomass in the +DOM boreal enclosures, as HNF are known to be efficient bacteria grazers (Laybourn-Parry \& Marshall 2003). BP showed a rapid reaction to the addition of subarctic DOM but such an increase was missing from the +DOM boreal enclosures. This suggests that boreal DOM might require a specific community to develop before it can be efficiently utilized. Using molecular microbial community analyses, Docherty et al. (2006) showed that, when exposed to a new DOM source, microbial communities will change within $72 \mathrm{~h}$ to correspond to the new source, regardless of the initial community structure. The fact that BP only increased at the beginning of the experiment was probably due to the combined effect of both the availability of DOC and nutrients, and the increased grazing pressure by $\mathrm{HNF}$ and mixotrophic algae.

Bacteria have been reported to react positively to DOC additions in many experiments (Eiler et al. 2003, Lennon \& Pfaff 2005), and especially when both DOC and nutrients have been added (Granéli et al. 2004, Jansson et al. 2006, Breton et al. 2009). However, none of these studies investigated DOM quality, which, according to results from this study, should be taken into account when assessing DOM influence on bacterial and other heterotrophic communities. In an earlier study of bacterial communities in the same area, DOM quality was found to influence bacterioplankton community composition while production was more controlled by DOM quantity (Roiha et al. 2012). In a comparable study by Hessen et al. (2004), there was a decrease in bacterial biomass induced by DOC additions, despite an increase in BP. However, in their experiment bacteria were heavily grazed by zooplankton that exhibited over a 4 -fold increase in biomass during the experiment. In our study, zooplankton was filtered out from the enclosures, but it is most likely that bacteria were still grazed by HNF, which increased in abundance throughout the experiment, especially in enclosures with elevated DOC.

While heterotrophic organisms showed a positive response to DOM additions, the variables representative of primary producers showed contrasting effects. Compared to the control enclosures, DOM additions led to a higher phytoplankton biovolume (+DOM subarctic) and higher numbers of picoautotrophs (+DOM boreal), but lower productivity, lower $\alpha^{*}$ and no statistical difference in chl $a$ or PNF. The reasons for primary producers not showing a consistently similar response to DOM additions are probably linked to resource competition with bacteria and picoautotrophs, and a shift from autotrophy to heterotrophy among mixotrophic algal species. Due to their smaller size, bacteria and picoautotrophs are more efficient in the competition for nutrients, compared to algae (Rhee 1972, Parker et al. 1975, Smith \& Kalff 1982, Callieri \& Stockner 2002), which may partly explain the increase of picoautotrophs in the +DOM enclosures. Higher biovolume, evidenced in +DOM enclosures, is considered unfavorable in low nutrient concentrations (Turpin 1991). However, high biovolume can also be an indicator of the increase of (large) cells capable of mixotrophy. Indeed, the phytoplankton community of the enclosures con- 
sisted of many mixotrophic species. Although mixotrophy was not specifically measured in the experiment, species that are known to be mixotrophic increased in the +DOM enclosures, especially the large colonial chrysophyte Uroglena sp (Table 2, Fig. 4C). Previous studies have shown that under low light intensity and/or when bacteria are added, the chlorophyll concentration per cell of mixotrophic algae reduces drastically (Sanders et al. 1990). The inconsistency in the ratio between chl $a$ and phytoplankton biovolume in our study is therefore best explained by the species composition of the study lake.

Previous work found both an increase (Hessen et al. 2004, Karlsson et al. 2007) and a decrease (Blomqvist et al. 2001) in PP due to DOC additions. In our experiment, DOC additions suppressed both $P^{*}{ }_{\max }$ and PP throughout the experiment. This could be another indication of a shift of mixotrophic species from auto- to heterotrophy with an excess carbon source. Previous studies showed that a threshold level of $10^{6}$ bacteria cells $\mathrm{ml}^{-1}$ is required for mixotrophic algae to shift from photosynthesis to bacterivory (Sanders et al. 1990), and this threshold was exceeded in the +DOM enclosures. Another explanation for the low PP in the + DOM enclosures might be that dissolved humic material had bound iron or some other metal that algae would require for photosynthesis (Guildford et al. 1987). Because the enclosures were relatively small, the amount of PAR was high enough for photosynthesis to take place in the whole water column in both the control and the +DOM enclosures.

Measured changes in heterotrophic and autotrophic microorganisms also resulted in important shifts in the relative importance between basal autotrophic and heterotrophic food web production and biomass. Although autotrophic biomass and production remained dominant in the experiment, increasing DOC concentration was accompanied by a shift from the heavy dominance of autotrophic productivity to a more even balance of production between autotrophs and bacteria, and decreases in the ratios of PNF to HNF and of autotrophic to mixotrophic algae. Our results, therefore, are in line with earlier studies (Jansson et al. 2000, Prairie et al. 2002) that showed that pelagic systems shift towards more heterotrophic based food webs with increasing DOC concentration. In addition, the increased microbial biomass in the +DOM enclosures most likely contributed to the increased concentration of total nutrients in the DOM treatments. Changes in the N:P ratio have been shown to override some of the positive effects of carbon additions to heterotrophic microbial food webs (Karlsson et al. 2002) but such changes did not take place in our experiment because the added DOM sources did not increase the inorganic pool of the treatment enclosures.

To place our mesocosm results in a broader context, we calculated how the increase in DOM would influence the whole lake PP. The current light climate in Lake Saanajärvi allows fully developed benthic algal communities to account for a considerable proportion of primary production in the lake (L. Forsström unpubl.). An increase in DOM comparable to the additions in this experiment would mean that the area available for benthic primary production would decrease from 83 to $34 \%$ of the total basal area of the lake. DOM would also decrease the euphotic layer for planktonic production, and reduce the depth of thermocline (Pérez-Fuentetaja et al. 1999). All these changes would lead to lower levels of PP and amplify the shift from autotrophy to heterotrophy. Previous studies have shown that phytoplankton concentration is lower at the very surface of Lake Saanajärvi, most likely due to photoinhibition (Forsström et al. 2005). An increase in DOM would protect algae from harmful UV radiation and photoinhibition, but for the total algal production of a relatively deep lake, such as Lake Saanajärvi, this has only a minor effect.

Extrapolating our results to the whole-lake level highlights one possible outcome of increasing DOM concentrations. However, further studies at different scales are needed to introduce more complexity and further assess the consequences of such changes. Mesocosm studies can never catch the complexity of whole ecosystems, and the results gained from such experiments have to be interpreted with caution (Schindler 1998, Ahn \& Mitsch 2002). For example, a comparison of phytoplankton growth rates between the open water and enclosures demonstrates how growth rates were lower in natural conditions (Table 2). The difference most likely results from a combination of the lack of predation and the constant high exposure to light in the enclosures. The only exception was a large colonial chrysophyte Uroglena sp. which has high mobility and is better able to escape predation than other algae in the lake because of its size (diameter of the colony up to $500 \mu \mathrm{m}$ ), explaining the very similar growth rate in natural and control environments. A large-scale ecosystem experiment would mimic natural conditions better, but due to problems related to logistics, costs and replicability, a whole-lake study was not possible on this occasion. However, since our experiment focused on the short-term effects on microscopic organisms 
with limited mobility, the results of our mesocosm study do represent a reasonable scenario of the outcomes of increasing DOM concentrations. A recent study comparing mesocosms of varying size up to 5000001 concluded that mesocosms can be used to determine the limiting factors for the growth of primary producers (Spivak et al. 2011).

In summary, our results have shown that doubling of DOC from 2.5 to $5 \mathrm{mg} \mathrm{l}^{-1}$ can shift the epilimnion of an oligotrophic, clear-water lake from a system dominated by an autotrophy-based food web towards a heterotrophy-based food web. Because DOM not only promotes bacterial growth but also affects the light climate, the change towards heterotrophy is even greater if the whole water column is taken into account. Our results also show that the quality of DOM that reaches the lake is highly important. The bacterial community was mainly influenced by the more degraded and bioavailable subarctic DOM, while the picoautotrophs and the ratio of autotrophic to mixotrophic algae were more affected by the more pigmented and possibly more allochthonous boreal DOM.

Acknowledgements. This study was supported by the Academy of Finland (Grants 119205 and 140775). We thank Mathieu Cusson for help with the statistics, Heather Mariash and Matteo Cazzanelli for assistance during fieldwork and Kilpisjärvi and Lammi Biological stations for use of their facilities during the laboratory work. We are also grateful to the anonymous reviewers for their constructive comments.

\section{LITERATURE CITED}

ACIA (2005) Arctic climate impact assessment. Cambridge University Press, New York, NY

Adams HE, Crump BC, Kling GW (2010) Temperature controls on aquatic bacterial production and community dynamics in arctic lakes and streams. Environ Microbiol 12:1319-1333

Ågren A, Buffam I, Berggren M, Bishop K, Jansson M, Laudon H (2008) Dissolved organic carbon characteristics in boreal streams in a forest-wetland gradient during the transition between winter and summer. J Geophys Res 113:G03031, doi:10.1029/2007JG000674

$>$ Ahn C, Mitsch WJ (2002) Scaling considerations of mesocosm wetlands in simulating large created freshwater marshes. Ecol Eng 18:327-342

> Arvola L, Salonen K, Kankaala P, Lehtovaara A (1992) Vertical distribution of bacteria and algae in a steeply stratified humic lake under high grazing pressure from Daphnia longispina. Hydrobiologia 229:253-269

Ask J, Karlsson J, Persson L, Ask P, Byström P, Jansson M (2009) Whole-lake estimates of carbon flux through algae and bacteria in benthic and pelagic habitats of clear-water lakes. Ecology 90:1923-1932

- Berggren M, Laudon H, Jansson M (2007) Landscape regulation of bacterial growth efficiency in boreal fresh- waters. Global Biogeochem Cycles 21:GB4002, doi:10. 1029/2006GB002844

Berggren M, Laudon H, Jansson M (2009) Hydrological control of organic carbon support for bacterial growth in boreal headwater streams. Microb Ecol 57:170-178

Berggren M, Ström L, Laudon H, Karlsson J and others (2010a) Lake secondary production fueled by rapid transfer of low molecular weight organic carbon from terrestrial sources to aquatic consumers. Ecol Lett 13: 870-880

Berggren M, Laudon H, Haei M, Ström L, Jansson M (2010b) Efficient aquatic bacterial metabolism of dissolved lowmolecular-weight compounds from terrestrial sources. ISME J 4:408-416

$>$ Biddanda B, Ogdahl M, Cotner J (2001) Dominance of bacterial metabolism in oligotrophic relative to eutrophic waters. Limnol Oceanogr 46:730-739

Blomqvist P, Jansson M, Drakare S, Bergström AK, Brydsten L (2001) Effects of additions of DOC on pelagic biota in clearwater system: results from a whole lake experiment in Northern Sweden. Microb Ecol 42:383-394

Breton JC, Vallieres C, Laurion I (2009) Limnological properties of permafrost thaw ponds in northeastern Canada. Can J Fish Aquat Sci 66:1635-1648

Callaghan TV, Johansson M, Anisimov O, Christiansen HH, Instanes A, Romanovsky V, Smith S (2011) Changing permafrost and its impacts. In: Symon C, Thing $H$, Pawlak J, Larson T (eds) Snow, water, ice and permafrost in the Arctic (SWIPA): climate change in the cryosphere. Arctic Monitoring and Assessment Programme (AMAP), Oslo, p 5-1-5-62

Callieri C, Stockner JG (2002) Freshwater autotrophic picoplankton: a review. J Limnol 61:1-14

De Lange HJ, Morris DP, Williamson CE (2003) Solar ultraviolet photodegradation of DOC may stimulate freshwater food webs. J Plankton Res 25:111-117

> Docherty KM, Young KC, Maurice PA, Bridgham SD (2006) Dissolved organic matter concentration and quality influences upon structure and function of freshwater microbial communities. Microb Ecol 52:378-388

- Eiler A, Langenheder S, Bertilsson S, Tranvik LJ (2003) Heterotrophic bacterial growth efficiency and community structure at different natural organic carbon concentrations. Appl Environ Microbiol 69:3701-3709

> Ekelund NGA (1993) The effect of UV-B radiation and humic substances on growth and motility of the flagellate Euglena gracilis. J Plankton Res 15:715-722

> Ellis BD, Butterfield P, Jones WL, McFeters GA, Camper AK (1999) Effects of carbon source, carbon concentration, and chlorination on growth related parameters of heterotrophic biofilm bacteria. Microb Ecol 38:330-347

Findlay SEG, Sinsabaugh RL (2003) Aquatic ecosystems: interactivity of dissolved organic matter. Academic Press, New York, NY

> Forsström L, Sorvari S, Korhola A, Rautio M (2005) Seasonality of phytoplankton in subarctic Lake Saanajärvi in NW Finnish Lapland. Polar Biol 28:846-861

Fry JC (1988) Determination of biomass. In: Austin B (ed) Methods in aquatic bacteriology. John Wiley \& Sons, New York, NY, p 27-72

Galford AE (2000) Small enclosures for aquatic ecology experiments. Am Biol Teach 626:424-428

> Granéli W, Bertilsson S, Philibert A (2004) Phosphorus limitation of bacterial growth in high Arctic lakes and ponds. Aquat Sci 66:430-439 
Guildford SJ, Healey FP, Hecky RE (1987) Depression of primary production by humic matter and suspended sediment in limnocorral experiments at Southern Indian Lake, northern Manitoba. Can J Fish Aquat Sci 44: 1408-1417

Guillemette F, del Giorgio PA (2011) Reconstructing the various facets of dissolved organic carbon bioavailability in freshwater ecosystems. Limnol Oceanogr 56:734-748

> Helms JR, Stubbins A, Ritchie JD, Minor EC, Kieber DJ, Mopper K (2008) Absorption spectral slopes and slope ratios as indicators of molecular weight, source, and photobleaching of chromophoric dissolved organic matter. Limnol Oceanogr 53:955-969

> Hessen DO, Blomqvist P, Dahl-Hansen G, Drakare S, Lindström ES (2004) Production and food web interactions of Arctic freshwater plankton and responses to increased DOC. Arch Hydrobiol 159:289-307

> Jackson TA, Hecky RE (1980) Depression of primary productivity by humic matter in lake and reservoir waters of boreal forest zone. Can J Fish Aquat Sci 37:2300-2317

> Jansson M, Bergström AK, Blomqvist P, Drakare S (2000) Allochthonous organic carbon and phytoplankton/bacterioplankton production relationships in clearwater and humic lakes. Ecology 81:3250-3255

Jansson M, Bergström AK, Lymer D, Vrede K, Karlsson J (2006) Bacterioplankton growth and nutrient use efficiencies under variable organic carbon and inorganic phosphorus ratios. Microb Ecol 52:358-364

Jefferey SW, Humphrey GF (1975) New spectrophotometric equations for determining chlorophyll a, b, c1 and c2 in higher plants, algae and natural phytoplankton. Biochem Biophys Pflanzen 167:191-194

> Jones RI (1992) The influence of humic substances on lacustrine planktonic food chains. Hydrobiologia 229:73-91

> Jones RI, Salonen K, De Haan H (1988) Phosphorus transformations in the epilimnion of humic lakes: abiotic interactions between dissolved humic materials and phosphate. Freshw Biol 19:357-369

Karlsson J, Jansson M, Jonsson A (2002) Similar relationship between pelagic primary and bacterial production in clearwater and humic lakes. Ecology 83:2902-2910

Karlsson J, Lymer D, Vrede K, Jansson M (2007) Differences in efficiency of carbon transfer from dissolved organic carbon to two zooplankton groups: an enclosure experiment in an oligotrophic lake. Aquat Sci 69:108-114

> Karlsson J, Byström P, Ask J, Ask P, Persson L, Jansson M (2009) Light limitation of nutrient-poor lake ecosystems. Nature 460:506-510

Kirchman D, K'nees E, Hodson RE (1985) Leucine incorporation and its potential as a measure of protein-synthesis by bacteria in natural aquatic systems. Appl Environ Microbiol 49:599-607

$>$ Klug JL (2002) Positive and negative effects of allochthonous dissolved organic matter and inorganic nutrients on phytoplankton growth. Can J Fish Aquat Sci 59:85-95

Kritzberg ES, Cole JJ, Pace ML, Granéli W, Bade DL (2004) Autochthonous versus allochthonous carbon sources of bacteria: results from whole-lake ${ }^{13} \mathrm{C}$ addition experiments. Limnol Oceanogr 49:588-596

- Laybourn-Parry J, Marshall WA (2003) Photosynthesis, mixotrophy and microbial plankton dynamics in two high Arctic lakes during summer. Polar Biol 26:517-524

> Lennon JT, Pfaff LE (2005) Source and supply of terrestrial organic matter affects aquatic microbial metabolism. Aquat Microb Ecol 39:107-119
Monteith DT, Stoddard JL, Evans CD, de Wit HA and others (2007) Dissolved organic carbon trends resulting from changes in atmospheric deposition chemistry. Nature 450:537-540

Montgomery DC (1991) Design and analysis of experiments. John Wiley \& Sons, Toronto

Moran MA, Hodson RE (1990) Bacterial production on humic and nonhumic components of dissolved organic carbon. Limnol Oceanogr 35:1744-1756

> Moran MA, Zepp RG (1997) Role of photoreactions in the formation of biologically labile compounds from dissolved organic matter. Limnol Oceanogr 42:1307-1316

> Morris DP, Zagarese H, Williamson CE, Balseiro EG and others (1995) The attenuation of solar UV radiation in lakes and the role of dissolved organic carbon. Limnol Oceanogr 40:1381-1391

> Parker RR, Sibert J, Brown TJ (1975) Inhibition of primary productivity through heterotrophic competition for nitrate in a stratified estuary. J Fish Res Board Can 32:72-77

> Pérez MT, Sommaruga R (2006) Differential effect of algaland soil-derived dissolved organic matter on alpine lake bacterial community composition and activity. Limnol Oceanogr 51:2527-2537

> Pérez-Fuentetaja A, Dillon PJ, Yan ND, McQueen DJ (1999) Significance of dissolved organic carbon in the prediction of thermocline depth in small Canadian shield lakes. Aquat Ecol 33:127-133

Platt T, Gallegos CL, Harrison WG (1980) Photoinhibition of photosynthesis in natural assemblages in marine phytoplankton. J Mar Res 38:687-701

Porter KG, Feig YS (1980) The use of DAPI for identifying and counting aquatic microflora. Limnol Oceanogr 25: 943-948

Prairie YT, Bird DF, Cole JJ (2002) The summer metabolic balance in the epilimnion of southeastern Quebec lakes. Limnol Oceanogr 47:316-321

Rae R, Vincent WF (1998) Phytoplankton production in subarctic lake and river ecosystems: development of a photosynthesis-temperature-irradiance model. J Plankton Res 20:1293-1312

Rautio M, Korhola A (2002) Effects of ultraviolet radiation and dissolved organic carbon on the survival of subarctic zooplankton. Polar Biol 25:469-473

Reynolds CS (2006) Ecology of phytoplankton. Cambridge University Press, Cambridge

Rhee G (1972) Competition between an alga and an aquatic bacterium for phosphate. Limnol Oceanogr 17:505-514

Roiha T, Tiirola M, Cazzanelli M, Rautio M (2012) Bacterioplankton productivity, seasonality and diversity in subarctic ponds. Aquat Sci 74:513-525

Safi KA, Hall JA (1997) Factors influencing autotrophic and heterotrophic nanoflagellate abundance in five water masses surrounding New Zealand. NZ J Mar Freshw Res 31:51-60

- Salonen K, Hammar T (1986) On the importance of dissolved organic matter in the nutrition of zooplankton in some lake waters. Oecologia 68:246-253

Salonen K, Hammar T, Kuuppo P, Smolander U, Ojala A (2005) Robust parameters confirm predominance of heterotrophic processes in the plankton of a highly humic pond. Hydrobiologia 543:181-189

Sanders RW, Porter KG, Caron DA (1990) Relationship between phototrophy and phagotrophy in the mixotrophic chrysophyte Poterioochromonas malhamensis. Microb Ecol 19:97-109 
Schindler DW (1998) Replication versus realism: the need for ecosystem-scale experiments. Ecosystems 1:323-334

Schuur EAG, Vogel JG, Crummer KG, Lee H, Sickman JO, Osterkamp TE (2009) The effect of permafrost thaw on old carbon release and net carbon exchange from tundra. Nature 459:556-559

Selinummi J, Seppälä J, Yli-Harja O, Puhakka JA (2005) Software for quantification of labeled bacteria from digital microscope images by automated image analysis. Biotechniques 39:859-863

SFS (Finnish Standards Association) (1990) Veden nitriittija nitraattitypen summan määritys. SFS 3030, SFS, Helsinki

SFS (2004a) Water quality: determination of nitrogen. SFSEN 12260, SFS, Helsinki

SFS (2004b) Water quality: determination of phosphorus. Ammonium molybdate spectrometric method. SFS-EN ISO 6878, SFS, Helsinki

Smith DC, Azam F (1992) A simple, economical method for measuring bacterial protein synthesis rates in seawater using ${ }^{3} \mathrm{H}$-leucine. Mar Microb Food Webs 6:107-114

Smith REH, Kalff J (1982) Size-dependent phosphorus uptake kinetics and cell quota in phytoplankton. J Phycol 18:275-284

Søndergaard M, Middelboe MA (1995) A cross-system analysis of labile dissolved organic carbon. Mar Ecol Prog Ser 118:283-294

Spivak AC, Vanni MJ, Mette EM (2011) Moving on up: Can results from simple aquatic mesocosm experiments be applied across broad spatial scales? Freshw Biol 56: 279-291

Editorial responsibility: Ruben Sommaruga, Innsbruck, Austria
Stewart AJ, Wetzel RG (1980) Fluorescence:absorbance ratios - a molecular-weight tracer of dissolved organic matter. Limnol Oceanogr 25:559-564

Talling JF (1957) The phytoplankton population as a compound photosynthetic system. New Phytol 56:133-149

Tulonen T (2004) Role of allochthonous and autochthonous dissolved organic matter (DOM) as a carbon source for bacterioplankton in boreal humic lakes. PhD dissertation, University of Helsinki, Helsinki

Turpin DH (1991). Physiological mechanisms in phytoplankton resource competition. In: Sandberg CD (ed) Growth and reproductive strategies of freshwater phytoplankton, Cambridge University Press, Cambridge, p 316-368

Utermöhl H (1958) Zur Vervollkommnung der quantitativen Phytoplankton-Methodik. Mitt Internat Verein Limnol 9: 1-38

Vincent WF, Laurion I, Pienitz R (1998) Arctic and Antarctic lakes as optical indicators of global change. Ann Glaciol 27:691-696

Vinebrooke RD, Leavitt PR (2005) Mountain lakes as indicators of the cumulative impacts of ultraviolet radiation and other environmental stressors. In: Huber UM, Bugmann HKM, Reasoner MA (eds) Global change and mountain regions: an overview of current knowledge. Springer, Dordrecht, p 437-448

> Weishaar JL, Aiken GR, Bergamaschi BA, Fram MS, Fujii R, Mopper K (2003) Evaluation of specific ultraviolet absorbance as an indicator of the chemical composition and reactivity of dissolved organic carbon. Environ Sci Technol 37:4702-4708

Submitted: May 30, 2012; Accepted: January 17, 2013 Proofs received from author(s): February 22, 2013 